\title{
Influence of Electronic Information Resources on Publication Output of Librarians in Niger Delta and Delta State University, Nigeria
}

\author{
Mercy Arodovwe IGERE \\ Department of Library and Information Science, Delta State University, Abraka PMB 1 Delta State, Nigeria. \\ * E-mail of the corresponding author: Email: mesonia1@yahoo.com, Tel no. +2348032320517
}

\begin{abstract}
The publication output of librarians in the past years has been observed to be very poor as most of the librarians complain of the difficulty in writing journal articles to publish in reputable journals. This brought about the investigation of the influence of electronic information resources on publication output of librarians in Niger Delta University Bayelsa and Delta State University, Abraka in Nigeria. The descriptive survey design was used in the study. Questionnaire was the instrument used in collecting data. The population for the study was made up of 30 librarians in Niger Delta University Bayelsa and Delta State University, Abraka. The entire population was used as sample because of its small size. Data were analyzed using simple percentage, descriptive statistics. The study found that the publication output level of the respondents in the universities sampled is low; the most used electronic resource are EBSCOHOST, HINARI, Open Access Journal, Open Access Books, AJOL, AGORA and Science Direct. The study also shows that there was no significant relationship between electronic information resources and publication output of librarians though electronic Information had a negative influence on the publication output of librarians. The study therefore recommends that librarians should make good use of electronic information resources which will positively influence publication output.
\end{abstract}

Keywords: Electronic, Information Resources, Publication Output, Librarians

DOI: $10.7176 / \mathrm{IKM} / 10-4-05$

Publication date: June $30^{\text {th }} 2020$

\section{Introduction}

Publication output is the number of outcome of a research published in journals, scholarly books that are recommended for librarians publications in a field relevant to his/her study and also provoke reactions by throwing up challenges to colleagues (Moed, Glanzel and Schmoch 2005). Similarly, Edem (2004:138) defined "publication output as the number of books, chapters in a book, occasional papers, technical report, patent, monographs, journal articles and other related research output such as bibliographies, abstracts and indexes that are published". In order words, the number of publications output is the number of research activities carried out that are documented for future research references. Madye (2007) referred to publication output as any research publication accepted for assessment by any evaluation body in order to promote an individual and other assessment or evaluation exercises. Russel and Ronald (nd) express that the production of a research unit is its number of publications. In order words Publication output is expressed as the number of publications per person in a year equivalents for research.

These publications therefore promote the librarians nationally and internationally thereby contributing to the knowledge of the public who will be able to access the information resource at a given period of time. In order for librarians to be able to publish both locally and internationally, there is need to have access to information resources. These information resources could be print and non print but presently there is increased use of electronic information resources but with the increased use of electronic information resources there are still complain on difficulty to publish. Studies and observation has shown that the publication output of librarian is low as a result of inadequate information resources. According to Okpe, Simisaye and Otuza (2013) that one of the reasons given for low publication output and effectiveness in Africa including Nigeria is an inadequate of information resource. That is, the comparatively lower research output of researchers in Nigeria and other developing countries is as a result of lack of access to adequate information resources, economic crises, libraries and information centers in Nigeria could no longer subscribe to current journals. Sharma (2009), stated that there is a high dependency value of research work carried out today and it is based on the use of current electronic information resources. Electronic information resources or simply electronic resources (e-resources) are knowledge kept electronically in computer device such as flash drives, digital libraries or the internet (Ani, 2013). This information in electronic format could be access at anytime and anywhere where there is network. When there is easy access to information resources it may improve on the research activities of the academics. Hence this study is set to examine:

- the publication output of librarians in the institution

- the electronic resources used by librarians 
- the influence of electronic information resources on publication output of librarians.

\section{Literature review}

Publication output is the quantity of articles published in standard journals or they are publications which are published in prestigious journals (Goel 2002). Publication output is the outcome of researches which appears in print and is usually embodied in research communications (Zainab, 2001). Zainab further provided a long list of publication output to include reports, books, journal articles, sections of books, technical reports, transactions, monographs, conference proceedings, peer reviewed bulletin, edited works, patents, standards and preprints. In order words, publication output is the number of quality research work done by academics and are published in a reputable journal. Yusuf (2005) stated that the output of publication of a researcher is a major index of an academic quality and the determinant of her advancement in the academic career. Okebukola (2002) stated that there was downfall of publications between the late 1980s and 1996 in Nigeria before its subsequent collapse from 1997. This downfall could be as a result of lack of training on research to develop manpower.

In another study, Oduwole and Ikhizama (2007) used survey method to ascertain research output of librarians in Nigerian agricultural research institutes. They found out that the librarians' research output generally was low. This was in relation to their work experience.

Akwegwu, Udida and Udey (2007) explained the importance of publication output based on its role in lecturers teaching effectiveness. They observed that lecturers teaching effectiveness depends to a large extent on research productivity. This is because lecturers who are involved in research to produce quality publication are expose to information resources in various field of knowledge. In a study carried out by Hart (2009) revealed that $80 \%$ of lecturers spent 19.8 hours per month on their research and this is as a result of the importance placed on publications. A quality and quantity publication output could be as a result of the information resources either in print form or electronic format accessed during research. In this technological era, though the library hold printed information resources, electronic information that could be easily accessed might be more useful. Egberongbe (2011) supported that the traditional library holds print information resources for users but in this technological era, the electronic information resources now stand as a great tool for research which supports the print information resources. Ani and Ahiauzu, (2008) also stated that institutional information centers today are moving from the traditional way of accessing information resources to the electronic information resources hence, electronic information resources are now a major information resource in every higher institution of learning and it has brought transformation into the way information is handled in Nigerian University communities (Ani, 2013).

Electronic information resources are resources in which information are stored electronically and they are accessible through electronic systems and networks. (Thanuskodi, 2012). In a like manner, Ndibuisi and Udo (2013) defined electronic information resources as the conversion of data into readable through the connection of some device through the internet network. That is to say, a user can access electronic information resource through computer related facilities like flash drive. The flash drive cannot be termed as electronic information resources but a source through which one access an electronic information resource (information system) or through which information is made available. . Ani and Ahiauzu, (2008) asserted that electronic information resources are available in computer disk read only memory (CD-ROM) database, , journals found online, database online, OPACs, Internet and other networks online. Electronic information resources are also available in various forms like electronic books, digital libraries, online journal, magazine, electronic learning tutors, on line test electronic journals, electronic discussions, electronic news, data archives, electronic mail, chatting online, image collection, other media products like numerical, graphical mode (Emwanta \& Nwalo 2013). Sivathaasan and Velnampy (2013), gave examples of some of the well known electronic resources as "electronic journals, standards, technical specifications, reports, patents, full text articles, trade reports and hosts of other". Most of the electronic information resources are accessible to users free anytime and anywhere for their academic research purposes. In the same way, users now have easy access and speed to more materials than could be made available in the print format. (Adeyemi, 2009). This is in line with the study of Udende and Azeez (2013) on Internet access and use among students of the University of Ilorin, Nigeria, it revealed that $315(81.8 \%)$ respondents agreed that their departments are connected to the internet as against the $66(17.1 \%)$ who disagreed, while $4(1 \%)$ did not respond. To the question of whether they acquired laptop or not, $143(37.1 \%)$ agreed whereas $242(62.9 \%)$ said they have not got a laptop. Similarly, 164(42.6\%) admitted that there is a cluster of computers at their disposal to access the internet as against the $221(57.4 \%)$ whose responses were on the contrary. This is an indication that they have access to the internet. This is to show that users find the electronic information resources advantageous to them in so many ways. Also, Agber and Agwu (2013) revealed that majority of the respondents of Agricultural science lecturers in tertiary institutions in Nigeria with $70 \%$ used electronic journals, $67.9 \%$ used electronic books, $87 \%$ used search engines such as Google and Yahoo, 82\% use encyclopedia such as Wikipedia, 57\% use theses, 51.8\% used indexes, 71.5\% used abstract, 72.5\% used dictionaries. CDROM, E-Granary and audio files were 45.6\%, 
44.6\%, 44.6\% respectively while web OPAC such as AGORA, OARE and HINARI was 45.6\%. It could be deduced from the study that lecturers in the institutions studied used electronic information resources, except for CD ROM and web OPAC, which could be because of lack of subscription by the institutions.

Dadzie (2007) outlined the advantages of electronic information resources that they are faster to consult, they are easy to use when combining words, they help to search for current files consisting of various components, and searched work could be printed or saved for future use. Through the use of electronic information resources, information is now available globally most especially for researchers publication. (Ellis \& Oldman 2005). Egberonge (2011) asserted that information that were restrained from users as a result of distance are now easily accessible and also current information are made available as well as other contents that are related. Siddiqui (2007) emphasized that the educational system has also benefited from the introduction of electronic information resources most especially in the aspect of distant learning. Researchers also do not depend on print information resources in the libraries which are in most cases unavailable or few in numbers to meet the need of users. Dadzie (2005) posited that electronic information resources could be used conveniently because of its accessibility from any location such as information center, library office, home etc. Easy accessibility to information resources brings about the use of information to researcher thereby improving their publication output. It is assumed that when information is accessible to researchers, it could be used for effective teaching and research. Adeniran, Issa and Bakare (2016) stated that easy access to information sources is a prerequisite to the success of effective delivery of quality information to the right people at the right time thereby improving publication of lecturers. Ng'etich (2004) reveal that there is increased web based research and research publications to the extent that any academic of any rank that does not utilize the Internet runs the risk of becoming irrelevant in his or her field. In order words, the use of electronic information resources in this present age is very important to researchers. The study by Ani, Ngulube, Onyancha (2014) to determine if there is positive effect between accessibility and utilization of electronic resources and productivity of academic staff in Nigerian Universities. The respondents were asked to indicate their level of accessibility and utilization of electronic resources in research as well as their productivity in terms of national, international, and total productivity between January 2005 and July 2012. The correlation analysis of the effect of accessibility and utilization of electronic resources on productivity of the respondents at the surveyed Universities indicated that there was significant positive correlation between accessibility and utilization of electronic resources and productivity of academic staff at the surveyed Universities $(r=0.135 ; p=0.015)$. This implies that increase in access and use of electronic resources will lead to increase in productivity among the respondents in the surveyed Nigerian universities. In a study carried out by Adeyemi (2009), assessing the impact of electronic resources on productivity of academics staff of Covenant University, Nigeria, the study revealed that the respondents considered electronic resources as enhancing their teaching productively. Computers $96 \%$, CDROM 18\%, Internet 84\%, Online Databases 34\%, Email 76\%, Electronic Journals 32\%, and Electronic Books $16 \%$.

\section{Methods}

The descriptive survey design was used in the study. The population for the study was made up of 30 Librarians from two universities, Niger Delta University, Bayelsa and Delta State University, Abraka. The researcher sampled the entire population because of it small size. The researcher used questionnaire to elicit information from the respondents and data were analyzed using descriptive statistics (percentages, mean and peason product moment correlation coefficient). 2.5 was used as criterion mean such that any item below 2.5 was rejected and any with 2.5 above was accepted and linear regression analysis was also used

\section{RESULTS AND DISCUSSION}

1. What is the level of publication output of librarians in the institutions? 
Table 1. level of publication output of librarians

\begin{tabular}{|l|l|r|r|l|}
\hline S/N & Level of Publication & Mean & \multicolumn{1}{l|}{ Std. Dev } & Remark \\
\hline 1. & Textbooks & 1.7778 & 1.28103 & low \\
\hline 2. & Chapters in books & 1.8148 & 1.14479 & low \\
\hline 3 & Single authored work & 1.9259 & 1.23805 & low \\
\hline 4. & Co-authored work & 1.7407 & 1.28879 & low \\
\hline 5. & Patent and certified invention & 1.2963 & 1.17063 & low \\
\hline 6. & Monographs & 1.5556 & 1.28103 & low \\
\hline 7. & Occasional papers & 1.2222 & 1.01274 & low \\
\hline 8. & Articles in learned journals & 2.0370 & 1.12597 & low \\
\hline 9. & Technical Reports & 1.3333 & 0.96077 & low \\
\hline 10. & Scientific peer-reviewed bulletin & 1.2593 & 0.98421 & low \\
\hline 11. & Conference proceedings & 1.6296 & 1.30526 & low \\
\hline
\end{tabular}

The above table reveals the publication output of librarians accessed during the study

Table 1 shows that the publication output of librarians in the study area is low as all mean score are below 2.50 which is the criterion mean. This corroborates the study of Okebukola (2002) that there was downfall of publications between the late 1980s and 1996 in Nigeria before its subsequent collapse from 1997. This downfall could be as a result of lack of training on research to develop manpower. And also the study of Oduwole and Ikhizama (2007) ascertained that the research output of librarians in Nigerian agricultural research institutes was generally was low. This was in relation to their work experience. The publication output of librarians is therefore low as each of the items sampled is below the criterion mean.

2. What are the electronic resources used by librarians

Table 2. Electronic Resources used by Librarians in the Study Area

\begin{tabular}{|l|l|r|r|}
\hline S/N & Electronic resources & Mean & \multicolumn{1}{l|}{ SD } \\
\hline 1. & HINARI & 2.9630 & 1.28547 \\
\hline 2. & AGORA & 2.7778 & 1.31071 \\
\hline 3 & EBSCOHOST & 3.0000 & 1.33012 \\
\hline 4. & OPEN ACCESS JOURNAL & 2.9630 & 1.15962 \\
\hline 5. & OPEN ACCESS BOOKS & 2.8148 & 1.21012 \\
\hline 6. & TEEAL & 2.3704 & 1.24493 \\
\hline 7. & OARE & 2.1852 & 1.21012 \\
\hline 8. & AJOL & 2.8148 & 1.30198 \\
\hline 9. & ARDI & 2.4074 & 1.21716 \\
\hline 10. & OAPEN & 2.0000 & 1.27098 \\
\hline 11. & SCIENCE DIRECT & 2.5185 & 1.34079 \\
\hline
\end{tabular}

The above table reveals the electronic resources used by librarians with the study area

Table 2 shows that the most used electronic resource is EBSCOHOST (3.00). HINARI (2.96), Open Access Journal (2.96), Open Access Books (2.81), AJOL (2.81), AGORA (2.78), and Science Direct (2.52) were also majorly used electronic resources. ARDI (2.41), TEEAL (2.37), OARE (2.19) and OAPEN (2.00) were not used frequently as their mean score of usage is below the benchmark of 2.50. This is an indication that the librarians make use of electronic resources. In line with the study, Agber and Agwu (2013) revealed that majority of the respondents with $70 \%$ used electronic journals, electronic books, search engines such as Google and Yahoo, encyclopedia such as Wikipedia, theses, indexes, abstract, dictionaries. CDROM, E-Granary and audio files, web OPAC such as AGORA, OARE and HINARI. 
3. What is the influence of electronic information resources on publication output of lecturers?

Table 3. the influence of electronic information resources on publication output of librarians?

\begin{tabular}{|c|c|c|c|}
\hline & & Publication Level & Electronic Resources \\
\hline \multirow[t]{2}{*}{ Pearson Correlation } & Publication Level & 1.000 & -.026 \\
\hline & Electronic Resources & -.026 & 1.000 \\
\hline \multirow[t]{2}{*}{ Sig. (1-tailed) } & Publication Level & & .448 \\
\hline & Electronic Resources & .448 & \\
\hline \multirow[t]{2}{*}{$\mathrm{N}$} & Publication Level & 27 & 27 \\
\hline & Electronic Resources & 27 & 27 \\
\hline
\end{tabular}

The above table reveals the influence of electronic information resources on publication output of librarians

Table 3 shows that there was no significant relationship between electronic information resources and publication output of librarians $(r=-0.026 ; \rho>0.05)$. Electronic Information had a negative influence on the publication output of librarians (Though this is negligible as the result presented shows that the relationship between electronic information resources and publication output of librarian is very weak. It is an indication that most of the use of electronic resources of librarians in the study area is not channeled toward publication, hence electronic information resource used is a negative influence on publication output. Though previous study revealed that the use of electronic resources positively influence publication output, this could be as a result of the difference in study area.

\section{Conclusion and Recommendations}

The advent of information communication technology has brought about ease in accessing information resources relating to every area of life. It is expected that with the influx of information resources as regard technology, there would be a positive influence on publication output but the study has revealed that the publication output of librarians in the study area is low. The study has shown that the librarians make use of electronic resources and electronic Information had a negative influence on the publication output of librarians. This is an indication that the use of electronic information resources is not channeled towards publications.

The following recommendations were drawn from the findings

- Librarians should work towards publishing as their promotion is tied to publication

- Librarians use of electronic resources should be towards publishing

\section{REFERENCES}

Adeniran, C.O Issa, A.O \& Bakare, A.A. (2016). Assessment of Information Accessibility and Utilization By State Agencies For The Control Of Hiv/Aids In North Central States Of Nigeria. International Journal of Digital Library Services. 6(1), 1-16 Retrieved from www.ijodlsin

Adeyemi A.O (2009). Assessing the impact of electronic resources on productivity of academic staff of Covenant University, Nigeria. Journal of library and information science. Jolis.6(1), 22-42. http://eprints.covenantuniversity.edu.ng/5083/1/assessing $\% 20$ the $\% 20$ impact $\% 20$ of $\% 20$ electronic $\% 20$ resources.pdf

Agber T.\& Agwu A.E (2013). Assessment of online resources usage by agricultural science lecturers of tertiary institutions in Benue State, Nigeria. American Journal of Research Communication. 1(10), 254-279. www.usa-journals.com

Akuegwu B.A. Udida L.A. \& Udey,U. (2007). Attitude towards quality research among lecturers in Universities in Cross River State -Nigeria. Paper presented at the 30th Annual National Conference of the Nigerian Association for Educational Administration and Planning held at the Faculty of Education Hall, Enugu State University of Science and Technology. Retrieved from http://www.academicjournals.org/

Ani, E. O. and Ahiauzu, B. (2008). Towards effective development of electronic information resources in Nigerian university libraries. Library Management, 29(6/7), 504-514. 
Ani O.E (2013). Accessibility And Utilization Of Electronic Information Resources For Research And Its Effect On Productivity Of Academic Staff In Selected Nigerian Universities Between 2005 And 2012. (unpublished phd thesis). http://uir.unisa.ac.za/bitstream/handle/10500/13057/thesis_.pdf?sequence=1

Ani, O.E., Ngulube, P. and Onyancha, B. (2014). Effect of accessibility and utilization of electronic information resources on productivity of academic staff in selected Nigerian universities. Science Research. 2(6), 166-171. Retrieved from http://www.sciencepublishinggroup.com/j/sr

Dadzie P.S (2007). Information Literacy: assessing the readiness of Ghanaian universities, Information Development. 23(4), 265-277. Retrieved from http://idv.sagepub.com/cgi/content/abstract/23/4/266

Edem, U.S. (2004). Academic qualifications: Their influences on publication output among librarians in Nigerian universities. Annals of Library Science and Documentation, 41(4), 135 - 143.

Egberongbe, H. S. (2011). The Use and Impact of Electronic Resources at the University of Lagos. Library $\begin{array}{llll}\text { Philosophy } \quad \text { and } & \text { Retrieved } & 2013 & \text { from }\end{array}$ http://www.webpages.uidaho.edu/ mbolin/egberongbe.htm

Ellis, D. \& Oldman, H. (2005). The English literature researcher in the age of the internet. Journal of Information Science 3 (1), 29-36.

Emwanta, M and Nwalo, K.I.V. (2013). Influence of computer literacy and subject background on use of electronic resources by undergraduate students in universities in South-western Nigeria. International Journal of Library and Information Science. 5(2), 29-42. Retrieved from http://www.academicjournals.org/IJLIS

Goel, K. (2002). Gender differences in publication productivity in psychology in India. Scientometrics 55(2), 243258.

Madye, S.M. (2007). The measurement of research output of public higher education institutions in South Africa: Hurdle or handle? Unpublished M.Ed Thesis, University of Pretoria.

Moed, H. F., Glanzel, W \& Schmoch, U. (2005). Handbook of quantitative Science and technology research: The use of publication and patent statistics in studies of $S \& T$ systems. Dordresht: Kluwer Academic Publishers.

Ndibuisi C. N. \& Udo N. (2013). Empirical study of motivation, challenges and strategies in the use of electronic information resources by postgraduate library users in South- east Nigerian Federal Universities. International journal of library and Information Science. 5(11): 468-473. http://www.academicjournals.org/

Ngetich, K. (2004). Old problem, new strategies: Internet as a tool for research in Africa. Retrieved from http://www.Codesria.org/links/conferences/elpubl/Ngetich.pdf.

Okpe, Simisaye and Otuza (2013). Research Output and Pattern of Publication among Faculty in Nigerian Private Universities: Babcock University Experience Information and Knowledge Management. 3(9); 64-70. www.iiste.org

Russel \& Roesseau (nd). Bibliometrics and Institutional Evaluation

Sharma, C. (2009). Use And Impact of e-Resources at Guru Gobind Singh Indrapratha University (India): A case study. Electronic Journal of Academic and Special Librarianship. 10(1), 1 - 8.

Siddiqui M.H (2007). Challenges of Educational Technology. New Delhi. APH Publishing Corporation pp.101105.

Sivathaasan N. \& ..Velnampy T. (2013), Use of Electronic Information Resources and Academic Performance of University Teachers: A case study. European Journal of Business and Management 5(14), 46-52 www.iiste.org 
Thanuskodi S (2012). Use of E-resources by the students and researchers of faculty of Arts, Annamalai University. Int. J. Lib. Sci. 1(1), 1-7

Udende P. and Azeez A.L. (2013). Internet access and use among students of the University of Ilorin, Nigeria. Journal of Communication and Media Research, Department of Mass Communication, Delta State University, Abraka, Delta State, Nigeria. 2(1),33-42 deltajournal@yahoo.com

Yusuf, M. O. (2005). Integrating information and communication technologies (ICTS) in Nigeria tertiary education. The African symposium. An Online Journal of Africa Education Research Network 5(2),43-50.

Zainab A.N. (2001) Library resources and services and publication productivity. Malaysian Journal of Library \& Information Science, 6(1). 71-79

Mercy A. IGERE, (M'2010) The author became a member of the Nigeria Library Association (NLA) in 2012 till date. She was born in 1978 in Abraka. She had a first and Master degrees in Library and Information science from Delta State University Abraka, Delta State in the year 2005 and 2011 respectively. She is currently running a PhD in Library and information Science at Nnamdi Azikiwe University Awka, Anambra State all in Nigeria. Her area of specialty includes Library management, Knowledge management and Information literacy skill. 